\title{
THÉOPHILE GAUTIER, La Mille et Deuxième Nuit et autres contes
}

\section{Lise Sabourin}

\section{(2) OpenEdition}

\section{Journals}

\section{Édition électronique}

URL : https://journals.openedition.org/studifrancesi/11946

DOI : $10.4000 /$ studifrancesi. 11946

ISSN : 2421-5856

\section{Éditeur}

Rosenberg \& Sellier

\section{Édition imprimée}

Date de publication : 1 avril 2018

Pagination : 154

ISSN : 0039-2944

\section{Référence électronique}

Lise Sabourin, " THÉOPHILE GAUTIER, La Mille et Deuxième Nuit et autres contes », Studi Francesi [En ligne], 184 (LXII | I) | 2018, mis en ligne le 03 juillet 2018, consulté le 17 novembre 2021. URL : http:// journals.openedition.org/studifrancesi/11946; DOI : https://doi.org/10.4000/studifrancesi.11946

Ce document a été généré automatiquement le 17 novembre 2021.

\section{(C) $\odot \Theta$}

Studi Francesi è distribuita con Licenza Creative Commons Attribuzione - Non commerciale - Non opere derivate 4.0 Internazionale. 


\title{
THÉOPHILE GAUTIER, La Mille et Deuxième Nuit et autres contes
}

\author{
Lise Sabourin
}

\section{RÉFÉRENCE}

THÉOPHILE GAUTIER, La Mille et Deuxième Nuit et autres contes, texte établi par Jean-Claude Brunon, Claudine Lacoste-Veyssere et Peter Whyte, Paris, Gallimard, 2016, «Folio 2€», 105 pp.

1 Signalons, dans la collection «Folio 2€» de Gallimard, la parution isolée, sans notice et avec fort peu de notes, de quatre contes extraits du volume de «La Pléiade», qui permettra à des enseignants désireux de faire étudier d'autres œuvres brèves de Gautier que La Morte amoureuse ou La Cafetière, de manipuler facilement Laquelle des deux, La Chaîne d'or, La Mille et Deuxième Nuit et Le Chevalier double, toutes histoires unifiées par la réflexion si chère à l'auteur sur le sort féminin, mais diversifiées par leurs contextes, anglais, grec, oriental et bohémien. 